Western Washington University Western CEDAR

2010

\title{
Designing a Writing Intensive Course with Information Literacy and Critical Thinking Learning Outcomes
}

Jeanne Armstrong Ph.D.

Western Washington University, jeanne.armstrong@wwu.edu

Follow this and additional works at: https://cedar.wwu.edu/library_facpubs

Part of the Library and Information Science Commons

\section{Recommended Citation}

Armstrong, Jeanne Ph.D., "Designing a Writing Intensive Course with Information Literacy and Critical Thinking Learning Outcomes" (2010). Western Libraries Faculty and Staff Publications. 47.

https://cedar.wwu.edu/library_facpubs/47 


\section{Page 1 of 15}

Designing a Writing Intensive Course with Information Literacy and Critical Thinking Learning Outcomes

Jeanne Armstrong

Western Washington University Libraries

Bellingham WA 98225-9103

360-650-7667

Jeanne.armstrong@wwu.edu

Jeanne Armstrong is a professor at Western Washington University and is the librarian liaison for several departments and programs, including American Cultural Studies, Anthropology, English, International Studies, Sociology, Women's Studies and Fairhaven College 


\begin{abstract}
:
Purpose: This article describes the process of redesigning the American Cultural Studies 499 course in order to integrate information literacy and critical thinking outcomes into specific assignments. Since this research and writing proficiency course at Western Washington University has traditionally been taught by a librarian with background in the discipline, the article also considers the challenges in communication between librarians and discipline instructors about the concepts of information literacy and critical thinking.

Methodology: Reviews of the literature on information literacy across the curriculum and on partnerships between librarians and discipline instructors will be combined with an analysis of the structure of the 499 course and the relevance of various sets of learning outcomes to the course.
\end{abstract}

Originality: Several proponents of information literacy across the curriculum have considered the challenges in communicating the importance of information literacy to discipline course instructors who usually emphasize "critical thinking" rather than information literacy. Since, this 499 course has always been taught by a librarian, this article can view this issue from the perspective of a librarian who is also the discipline instructor for this writing proficiency course. Practical Implications: With more pressure on higher education to demonstrate the relevance and benefits of educational programs, this article has the potential of enhancing communication among librarians and discipline instructors by considering the continuum between information literacy and critical thinking and the advantages of embedding information literacy or library research training into writing intensive courses.

Keywords: Information literacy, critical thinking, teaching methods, redesign.

\title{
Introduction
}

Historically the librarian assigned to liaison with the American Cultural Studies Program at Western Washington University has taught the four credit research and writing intensive course required by all majors in the program, American Cultural Studies 499 cross-listed as Library 499. The main assignment for the course is a fifteen page research paper. As the liaison for American Cultural Studies, the author has taught this course every year since 2003.

Instruction librarians at Western Libraries have developed a set of learning objectives for library instruction. However, integrating these objectives into our instruction program is an ongoing process. While the subject liaison librarians are frequently invited to give instruction in writing proficiency discipline courses, they have not entirely convinced discipline faculty to embed and assess library research instruction in these courses in order to ensure that students acquire information literacy competencies.

The literature on information literacy in the disciplines often mentions the communication gap between librarians and discipline course instructors. This article describes the author's process of embedding learning outcomes into the 499 writing proficiency course in which the librarian is also the discipline instructor. Hopefully this experience can enhance the ability of librarians to communicate with discipline instructors about information literacy and critical thinking across the disciplines. In 2007 a summer teaching grant provided an opportunity to spend time reading the literature and redesigning the course in order to analyze the relationship of critical thinking and information literacy outcomes to the assignments. 


\section{Page 3 of 15}

\section{Literature Review}

While there is a substantial amount of literature about information literacy and instruction in academic libraries, this review focuses on specific literature about embedding information literacy in discipline credit courses. Two relevant articles are "Developing Information Literacy and Research Skills in Introductory Psychology: A Case Study," by Larkin and Pines and "Reflections on Collaboration: Learning Outcomes and Information Literacy Assessment in the Business Curriculum" by Fiegen, Cherry and Watson (Larkin and Pines, 2005; Fiegen et al., 2002). Invited by the librarians to conduct focus groups with students about their experiences of the library, Larkin and Pines, psychology professors, discovered that students did not have adequate information literacy skills. These professors, however, were reluctant to give up class time for an instruction session taught by a librarian so they decided to design a class project which would require learning information retrieval skills with a "minimal amount of in-class instructional time" (Larkin and Pines, 2005 p. 41). They explained to the students that the purpose of the assignment was to improve their information literacy skills and they gave them clear, written instructions on locating and using the library's databases. Larkin and Pines asked a librarian to participate in assessing this intervention. The librarian provided the " "blind' ratings [which] constituted our evaluation of student information literacy" (Larkin and Pines, $2005 \mathrm{p}$. 43). While they cooperated with librarians in the development and assessment of the information literacy project, the psychology professors, not the librarians, taught research skills to the students.

The article by Ann Fiegen, Bennett Cherry, and Kathleen Watson concerns information literacy in the business curriculum. Four core business courses were identified as appropriate for addressing information literacy competencies. The faculty teaching these courses used an assessment planning matrix presented by Lowell and Collins at an ALA pre-conference workshop and "identified their course objectives, described the instruction method and/or course assignment that related to the course objective, and then identified the learning outcomes expected for each objective" (Lowell and Collins, 2001; Fiegen et al., 2002 p. 309). A primary goal of this exercise was to assist teaching faculty in relating the information literacy outcomes to class assignments. This effort to integrate information literacy in the curriculum demonstrated a strong collaboration between librarians and business faculty. In the process of identifying the relationship between learning outcomes and their course assignments, the librarians worked with groups of faculty who taught each course. Then the librarians made presentations to the classes on how to search business databases and how to evaluate the quality of their sources. In conclusion, the authors mentioned the benefits of their cross disciplinary approach because librarians had the "opportunity to observe professors reflect on course objectives and how information competencies matched those objectives" (Fiegen et al., 2002 p. 316).

A slightly different approach is taken in "Reading, Writing, Research: Incorporating Strategies from Composition and Rhetoric into Library Instruction" by Alexandria Peary and Linda Ernick. This article describes the collaboration between a freshman English course instructor and a librarian for the purpose of integrating library instruction into course content (Peary and Ernick, 2004). The research component in this course was more integral to the goals of the course than is typical in many of the collaborations between librarians and instructors of discipline courses. The librarian had a one-on-one consultation with each student about the research process. The librarian and instructor used techniques from teaching composition skills, 


\section{Page 4 of 15}

specifically 'staging the process,' which breaks the research and writing process into manageable steps, and shared responsibility for teaching and grading.

\section{Course Design}

While using some of the strategies mentioned by Peary and Ernick such as one-on-one meetings and staging the process, this author's effort to examine and make explicit the information literacy and critical thinking outcomes of the capstone American Cultural Studies 499 differs from these other endeavors. Because she has a Ph.D. in comparative cultural studies, the author is able to serve as both librarian and discipline instructor for this course. Her intention was to develop outcomes which would combine information literacy with critical thinking.

American Cultural Studies students are allowed to design their majors, which can emphasize ethnic studies (American Indian, African American, Asian American, Raza Latina) or lesbian, gay, bisexual, transgender studies. The author's initial 2003 design of the 499 course used one-on-one consultations in place of some class sessions; required a research paper as the final project; and allowed the students to choose their topics as long as the topics were relevant to the ACS curriculum. In 2004 the research paper assignment was modified so students could have the option of creating either a thesis driven paper or a literature review paper.

While learning outcomes always informally guided the organization of the course material, due to a University wide mandate for assessment measures, there was a need in 2007 to more explicitly embed critical thinking as well as information literacy in the course and use outcomes to measure the success of the course. The summer 2007 teaching grant provided sufficient release time from daily duties to do an in-depth review of the course and to develop learning outcomes for it. This summer project provided time to read articles and books related to the pedagogy of teaching college writing and the pedagogy of teaching an upper level cultural studies or ethnic studies course.

Since Western Washington University has a three quarter academic year rather than a two semester academic year, students need to choose a topic and commence the research process immediately. Then students read sources on their topics and synthesize information from scholarly articles, books and other resources. The instructor's role in the course is partly as a teacher of research methods and partly as a facilitator who helps the students improve their research methods and create their papers by supporting their work at every stage of the research and writing process. The students are always assigned readings on the research process, which are discussed in class. In 2008 for example, two of these readings were, "Selecting a Topic and Identifying Literature for Review" in Writing Literature Reviews and "Developing a Research Strategy" in The Curious Researcher (Galvan 1999; Ballenger, 2007). The text for the 2010 course was Craft of Research by Wayne C. Booth, Gregory G. Colomb, Joseph M. Williams.

Students must choose topics by the second class so that the next sessions can focus on research methods and resources relevant to their topics. There are three sessions of instruction on research methods, which cover the online catalog, a regional catalog called Summit, interlibrary loan, primary sources, government information, databases and appropriate Internet sources. In one session, students examine several reference books which are relevant for finding overview or literature review articles on their topics; for identifying concepts; and for finding resources listed in the bibliographies of relevant entries. Students also learn the process of cited reference searches to access more resources on their topics. In locating, analyzing and synthesizing the 


\section{Page 5 of 15}

information on their topics, they experience the continuum between the research or information literacy process and the critical thinking process.

The assignment sequence is designed to move students through the logical stages of the research and writing process and also to engage them in the dialectical relationship between research and critical thinking. Based on student feedback, most students indicate their appreciation of this staging of the research and writing process as enabling them to succeed in the completion of their papers.

The initial assignment for the course has always been to read and analyze one or more articles or readings for a group discussion. This is the only assignment that all students have in common and which therefore allows them to collaborate in the critical thinking process. There have been minor variations in this initial assignment over the years. In 2005, the initial assignment was changed to require that students choose one of four electronic reserve articles to read and analyze. The analysis assignment should identify the author's thesis and the evidence used to support the thesis.

For the past few years, all students have read the same assigned article for their first article analysis assignment. One such article was "Textualism, Morality and the Problem of History" by Jane Tompkins. Though this article focuses on American Indians, it also fosters interpretive reading methods, since it discusses the ambiguity of information and the challenge of trying to determine the 'facts' by piecing together or synthesizing divergent perspectives (Tompkins, 1994). Tompkins's article fosters critical thinking by assisting students in understanding the complexity of information and the wisdom of not assuming that there is simply one correct perspective rather than a myriad of perspectives that bring to light various aspects of an issue.

Thus this first article analysis on a shared reading provides a common ground for students enabling them to discuss their analysis of this reading as a group. The second and third article analysis assignments require each student to locate and analyze an article relevant to his/her topic. The assignment of designing the research strategy is important as this will demonstrate to both the student and the instructor whether the student is prepared to follow an effective research process toward accomplishing the final objective of writing the research paper. After using some designated computer lab time in class and some time outside class to research their topics, the students must submit by midterm an annotated bibliography with the twelve minimum scholarly sources required for the final paper. In addition to the bibliography assignment, the outline assignment is a pivotal exercise. Once the students have created a strong annotated bibliography and a well-organized outline, they should be prepared to write their papers.

\section{Redesign Project}

The summer teaching project was an opportunity to revise this capstone course in order to create a more analytical approach to student research and writing and to select course learning objectives which address critical thinking as well as information literacy. Several sets of learning objectives were examined including the learning objectives for American Cultural Studies (http://www.wwu.edu/acs/about.shtml), which the author helped create; the standards for the Anthropology and Sociology Section of ACRL (http://www.ala.org/ala/mgrps/divs/acrl/standards/anthro_soc_standards.cfm) and the learning 


\section{Page 6 of 15}

outcomes for Western Libraries' instruction program

(http://www.library.wwu.edu/ref/inst/info_lit_outcomes.htm).

During this process, it seemed important to examine and more clearly articulate the relationship between information literacy and critical thinking. The author reviewed some literature which touches on the challenge of communicating with faculty across disciplines without using library jargon in order to convince them to give up valuable class time for library research instruction. James Elmborg's article, "Information Literacy and Writing across the Curriculum," compares the prospect of creating information literacy across the curriculum to the writing across the curriculum movement. He comments that, "the daily language used by many librarians in talking about information literacy lacks the critical dimension it needs to work with WAC" (Elmborg, 2003 p. 71). Elmborg observes that the research process is different according to each discipline and suggests that librarians need to learn the customs of the disciplines in order to help students engage in these scholarly communities. He also mentions "critical pedagogy," based on constructivism, post-structuralist theory and anthropology as an approach, which allows "students to claim control of their own education" and foster "critical consciousness"(Elmborg, 2003 p. 71).

In her article "A Discipline-Based Approach to Information Literacy," Ann Grafstein urges shared responsibility for information literacy throughout the academic institution. She emphasizes that the "concept of IL that has been adopted in this article is one that contextualizes it within the structures and modes of thought of particular disciplines . . . being information literate crucially involves being literate about something" (Grafstein, 2002 p. 202). "The What and Who of Information Literacy and Critical Thinking in Higher Education" by Rebecca S. Albitz is a significant article about the communication gap between librarians who discuss information literacy and faculty who focus on critical thinking (Albitz, 2007). Albitz begins by asking why teaching faculty are so resistant to allowing librarians into their classroom to give instruction on information literacy and claims that librarians are not participating in the conversation about critical thinking in the academic curriculum. Her observation that "these two groups are not using the same language when they discuss very similar concepts" may explain why many undergraduates lack the most basic skills needed to finding relevant sources for their research projects (Albitz, 2007 p. 97).

A Western Libraries colleague, Jeff Purdue, wrote an article analyzing the reaction of some discipline faculty to the perceived library jargon of the phrase information literacy. $\mathrm{He}$ states that "when we call the concepts embodied by 'Information Literacy' by that name, we engage in unintentional obfuscation" (Purdue, 2003 p. 653). Purdue asks how librarians can expect others to understand the meaning of this concept when even they are confused about information literacy, for example whether it is a skill or a cognitive process. He prefers to consider information literacy as a continuum, citing Christine Bruce's article in which she defines seven levels along a continuum from information technology to wisdom (Purdue, 2003 p. 657). Purdue proposes that information literacy should be treated as a transformative research engagement which includes knowledge production.

In his dissertation, A Case Study of Faculty Perceptions of Information Literacy and Its Integration into the Curriculum, Monty McAdoo reviews the literature on library instruction, search strategies and information literacy in an effort to define the concept of IL and determine how discipline faculty comprehend it. He quotes Lawrence McCrank's statement that "information literacy is difficult to define but easier to describe because it is an abstraction." Yet most of those discussing information literacy skills or techniques agree that these skills should 


\section{Page 7 of 15}

"be transferable to multiple information environments" (McAdoo, 2008 p. 39). McAdoo cites the literature which demonstrates that the responsibility for information literacy instruction is seen as a library responsibility, not a "shared responsibility" (McAdoo, 2008 p. 43). He believes that the perception of information literacy as a skill belonging to the library is a disadvantage since this perception obstructs the integration of information literacy into the curriculum. McAdoo states that discipline faculty members understand the importance of teaching critical thinking to students and recognize that information literacy is a foundation for critical thinking.

Referring to Rise Smith's paper, "Philosophical Shift: Teach the Faculty to Teach Information Literacy" McAdoo proposes that "a new role for librarians may be to focus on educating the faculty rather than the students" (McAdoo, 2008 p. 63). Being aware of discipline specific needs and understanding faculty's ability to conceptualize information literacy are both essential to communicating with them about embedding IL in their courses. In this 1997 ACRL paper, Smith promotes the "teach the teachers" approach through which librarians offer workshops to faculty on library research instruction. According to Smith, the key components for success in this endeavor include training faculty in the use of "information systems and services. . . and in techniques and activities that can be used to develop student information literacy" (Smith, 1997 p. 3).

This literature on critical thinking, information literacy and cultural theory provided ideas on how to embed these concepts into the design, assignments and learning outcomes of the 499 course and also on how to communicate with discipline faculty about the importance of information literacy in the development of critical thinking abilities. Redesigning and strengthening this capstone American Cultural Studies 499 course in a way that more clearly articulates the learning objectives as life-long research and writing skills would further foster the success of students in their graduate programs and careers and potentially serve as a template for embedding the information literacy and critical thinking process in assignments for other writing intensive courses.

\section{The Learning Outcomes}

Considering the importance of bridging the communication gap between the terminology of information literacy and critical thinking, it was important to create course outcomes which would illustrate the continuum from information literacy through critical thinking to knowledge production in the form of a research paper. As a result of reading the literature of pedagogy and reviewing the course design during the summer project, this author identified twelve relevant outcomes selected primarily from the American Cultural Studies outcomes and the Anthropology and Sociology Section standards as relevant and connected them to course assignments.

Appendix A has a complete list of outcomes with attached assignments. This table is an abbreviated version of the outcomes aligned with the assignments which measure the outcomes.

\section{Short Version of Outcomes}

1-Examine relationships that are shaped by inequalities of power and identities

2-Apply relevant methodologies and skill to contribute to the field of American cultural studies

3-Identify and describe a manageable research topic

\section{Assignments for Outcomes}

All assignments

All assignments

Topic statement 
4-Read background sources relevant to the topic

5-Identify and list key concepts, terms, social theories etc.

6- Refine the question

7-Select the most appropriate sources and databases

8-Construct and implement a search strategy

9-Summarize and synthesize main ideas from sources to construct new concepts

10-Seek differing viewpoints

11-Compare new knowledge with prior knowledge ... and record and determine adequacy of sources

12-Plan, create and revise the research paper
Article analyses

Research strategy

Revised topic statement

Research strategy

Research strategy

Article analyses/bibliography

Annotated bibliography

Annotated bibliography

Draft and final paper

The process of identifying which assignments would demonstrate accomplishment of the outcomes was an important aspect of integrating these learning outcomes into the course. For example outcome four, "read background sources in discipline relevant to the topic" is satisfied by the second and third article analysis assignments. The students choose two articles which are relevant to their topic for these assignments. They are required to identify the author's thesis, the evidence used to support the thesis and any examples of theory used by the author.

Outcomes five, seven and eight are satisfied by the research strategy assignment (Appendix B). Outcomes nine, ten and eleven are fulfilled by successfully completing an annotated bibliography which should demonstrate that the student has selected seminal sources covering various perspectives on the issue. The syllabus specifies that the bibliography should include a minimum of twelve scholarly sources and a minimum of four journal articles that have been identified by using discipline specific databases, such as Sociological Abstracts or ERIC.

Outcomes one, two and three address students' demonstration of critical thinking ability. The student research paper should "examine relationships that are shaped by inequalities of power and identities, . . . apply relevant methodologies and acquire requisite oral and writing skills that will enable students to contribute to the field of American cultural, ethnic and multicultural studies." Other outcomes related to critical thinking rather than solely information literacy are outcome nine that requires synthesizing the main ideas from sources "to construct new concepts" and outcome eleven, which concerns comparing "new knowledge with prior knowledge to determine the value added, contradictions, or other unique characteristics of the information and take steps to reconcile differences."

In addition to selecting learning outcomes for the 499 course and relating them to the assignments, the course was redesigned to have more meetings in a computer lab so that students could either use computers to conduct research or to start writing a draft of their final papers. A useful book on teaching the writing process, Rewriting: How to Do Things with Texts by Joseph Harris, moved this author's focus toward a better balance between teaching research skills and engaging students in the process of writing and rewriting drafts as a method of learning critical thinking (Harris, 2006).

\section{Assessment}

One of the traditional methods of assessing achievement of information literacy learning outcomes in credit courses or bibliographic instruction has been through evaluation of the bibliographies in students' research papers. There is a long history for this analysis of student 


\section{Page 9 of 15}

research papers as an assessment strategy dating back to the $1982 \mathrm{Kohl}$ and Wilson article, "Effectiveness of Course-Integrated Bibliographic Instruction in Improving Coursework" (Kohl and Wilson, p. 1982). Some recent literature includes "Check the Citation: Library Instruction and Student Paper Bibliographies" by Hovde and "Using Rubrics to Assess Information Literacy” by Knight (Hovde, 1999; Knight, 2006). Hovde's article discusses an assessment of student papers for a freshman English class in which students were given instruction on appropriate online catalog and database searches. The English instructors informed their students that their bibliographies should include journal articles, not popular magazine articles, as well as books. Hovde examined the bibliographies and did an analysis of citation type as well as the source of the article citations. She found that $47.69 \%$ of citations were books and $42.1 \%$ were journals or magazines. She also determined that $63.28 \%$ of the articles were found through the Wilson network and $21.09 \%$ through the SilverPlatter network (Hovde, 1999). Hovde concluded that the students were using the databases demonstrated during the instruction session and thus their sources were generally appropriate for the research assignment.

Knight's article discusses the application of grading rubrics to a freshman course that has information literacy as an outcome. She collaborated with several faculty members to develop a rubric to match learning objectives with performance indicators and outcomes. For example, the objective on locating scholarly books and articles has as one indicator, "identifies a variety of potential sources of information" (Knight, 2006 p. 47). Another rubric measured levels of achievement. The objective of locating reputable information is measured as 'beginning' if all sources are from magazines or the web; as 'proficient' if three sources are from scholarly journals; and as 'advanced' if five sources are from scholarly journals (Knight, 2006 p. 48). Knight applies the rubric to 260 bibliographies, each containing ten citations. She then provides a breakdown for the percentages of students in regular, honors or service courses attaining either beginning, proficient or advanced levels. Her conclusion was that the rubric benefits efforts to measure successful research instruction. For example, they were able to revise the library's online tutorial in response to problems identified through the study.

In their 1995 article, Virginia Young and Linda Ackerson also examine student bibliographies by applying criteria based on earlier literature such as the Kohl and Wilson article previously cited (Young and Ackerson, 1995). They primarily relied on the three evaluation criteria used by Kohl and Wilson but had librarians, rather than writing instructors, rate the bibliographies. The three criteria were: appropriateness of the type of source with journals rated higher than books since currency was important; appropriate use of retrospective and contemporary sources; and quality of the source with scholarly refereed journals rated highest (Young and Ackerson, 1995 pp. 85-86).

While such detailed rubrics are not applied to the bibliographies in the 499 papers, the students are required to use a minimum of twelve scholarly sources, including four scholarly articles identified by searching discipline databases. In addition to the instruction on library research, students are given information on how to distinguish between a scholarly versus a popular article and how to develop a research strategy. The research strategy guidelines (see Appendix B) require students to identify the types of sources appropriate to the topic, for example primary sources, mainly articles or mainly books. The research strategy should also list databases relevant for researching the topic and keywords to search.

Though student evaluations are one measure of assessing the course, successful completion of the research paper with the requisite number of scholarly sources is a qualitative measure for the course. Over the years all of the students have successfully completed their 


\section{Page 10 of 15}

research papers with most performing B or A level work. Every year since 2005, three to four students from each class have been selected to present their papers in a Scholars Week panel at Western, which is another indicator of achieving the course's outcomes. In Jeff Purdue's article, he mentions that a student became disengaged from the passion which inspired her to choose a research topic because of assumptions about the appropriate style of academic writing. Years ago this author was influenced by Jane Tompkins' article, "Me and My Shadow," in which she proposes that knowledge need not be founded on the denial of emotion. Thus 499 students are encouraged to write passionately but also to clearly identify their positions or identities and their personal investments in their topics.

\section{Conclusion}

The OCLC paper, "Perceptions of Libraries and Information Resources" provides statistical evidence that $50 \%$ of college students learn about electronic resources, such as databases, from their teachers compared to 33\% from a librarian (De Rosa, 2005 p. 1-20). Given this data, it is even more important that academic librarians learn to partner with discipline course instructors in order to teach them methods to share with their students and thereby embed research skills into their courses.

The potential for continuing to develop conversations between librarians and discipline faculty is enhanced whenever we engage in discussions that enable us to recognize the relationships between the pedagogies of information literacy and critical thinking and to develop partnerships between librarians and discipline faculty. In spring 2008, Western Libraries hosted a panel on "Fostering Critical Thinking and Preventing Plagiarism." This author moderated the panel of discipline faculty from English, sociology and environmental studies, who discussed different methods of integrating information literacy or critical thinking into their courses in order to prevent plagiarism.

Two of the panelists specifically described staging steps in the research paper process as a method of preventing intentional or unintentional plagiarism. Sociology professor James Inverarity's talk, "Student Plagiarism as an Attractive Nuisance Problem," explained the problem as resulting from assignments that can create a "hazardous condition for students that are unable to recognize the risk of plagiarism." English professor Mary Janell Metzger discussed the "politics of education" that influences student attitudes about plagiarism and suggested some "scaffolding strategies for eliminating the need and ability of students to plagiarize." The strategies they described for staging or scaffolding the research paper process are very similar to the staged assignments in the American Cultural Studies 499 course and there have been no occurrences of plagiarism during the eight years this author has taught the course. This panel discussion moderated by a librarian who shares the panelists' experiences with teaching writing proficiency courses provided an excellent opportunity to communicate across discourses of information literacy and critical thinking.

According to Gary Thompson, if "information literacy is to be embedded into courses, then faculty must accept some level of responsibility for teaching these skills, whether" they are taught by discipline faculty or librarians (Thompson, 2002 p. 228). He also asserts that librarians, on the other hand, should become more familiar with course objectives and pedagogy in the disciplines. Librarians should not assume that discipline faculty members understand all the resources or research strategies in their disciplines. Opportunities to make presentations on resources and research strategies to department faculty or to assist faculty members with their 


\section{Page 11 of 15}

research problems or their students' research problems can facilitate the process of seamlessly embedding "information literacy" or research strategy skills into discipline research and writing proficiency courses.

The author's experience with developing learning outcomes for the American Cultural Studies 499 research and writing course enabled this librarian-instructor to better understand the relationship between information literacy and critical thinking and recognize these abilities as a continuum. This insight has resulted in improved instructional methods and course assignments. In recent years changes have included: requiring students to use three to four sources identified by searching a discipline database; having students revise their drafts based on student peer reviews before submitting the drafts to the instructor; and giving students a pretest to determine their research and information literacy skills. As the pretest revealed, although the students had used databases to find articles, only a few students had previously used discipline specific databases while the majority had used only interdisciplinary full-text databases such as EBSCO and JSTOR.

The experience of creating these outcomes has also enhanced the ability of this author as librarian-instructor to communicate with the discipline faculty whose students she assists with their research. Although the author has a discipline Ph.D. in addition to a Masters degree in library science, communication between librarians and discipline instructors at Western about research skills has mainly been facilitated by the fact that librarians have faculty status and often partner with discipline faculty in team teaching courses.

This article, which provides an example of communicating across boundaries by examining the issues through the combined lens of a librarian, who is also a writing proficiency instructor, might be a bridge across the discourse gap between information literacy and critical thinking. Such a bridge can be useful for communicating with discipline instructors and convincing them to view information literacy and critical thinking as elements on a continuum in the research and writing process necessary for discipline based writing proficiency courses.

\section{REFERENCES}

Albitz, R. S. (2007), "The What and Who of Information Literacy and Critical Thinking

in Higher Education", portal: Libraries and the Academy, Vol. 7 no.1, pp. 97-109.

American Cultural Studies Program, Western Washington University. "American

Cultural Studies Student Learning Outcomes."

http://www.wwu.edu/acs/about.shtml. [accessed 7 August 2008].

Anthropology and Sociology Section ACRL. "Information Literacy Standards for

Anthropology and Sociology Students."

http://www.asanet.org/galleries/pubinfo/ALA\%20Information\%20Literacy\%20Standards.pdf.

[Accessed 29 March 2010].

Armstrong, J. "American Cultural Studies 499 Syllabus 2008."

http://www.library.wwu.edu/ref/subjects/amculturalstudies/amst_499.htm

[Accessed 29 March 2010].

Ballenger, B. ( 2007), Curious Researcher, Longman, New York, NY.

Booth, W. C., Colomb G. G., and Williams, J. M. (2008), The Craft of Research, University of Chicago Press, Chicago.

De Rosa, C. et al. (2005), Perceptions of Libraries and Information Resources, OCLC

Online Computer Library Center, Dublin, Ohio. 


\section{Page 12 of 15}

Elmborg, J. K. (2003), "Information Literacy and Writing across the Curriculum: Sharing the Vision", Reference Services Review, Vol. 31 no.1, pp. 68-80.

Fiegen, A. M., Cherry, B. and Watson, K. (2002), "Reflections on Collaboration: Learning Outcomes and Information Literacy Assessment in the Business Curriculum", Reference Services Review, Vol. 30 no. 4, pp. 307-318.

Galvan, J. (1999), Writing Literature Reviews: A Guide for Students of the Social and Behavioral Sciences, Pyrczak, Los Angeles.

Grafstein, A. (2002), “A Discipline-Based Approach to Information Literacy”, Journal of Academic Librarianship, Vol. 28 no. 4, pp.197-204.

Harris, J. (2006), Rewriting: How to Do Things with Texts, Utah State University Press, Logan, Utah.

Hovde, K. (1999), "Check the Citation: Library Instruction and Student Paper Bibliographies," Research Strategies, Vol. 17 no. 1, pp. 3-9.

Knight, L. (2006), "Using Rubrics to Assess Information Literacy”, Reference Service Review, Vol. 34 no. 1, pp. 43-55.

Kohl D.F. and Wilson, L.A. (1982), "Effectiveness of Course-Integrated Bibliographic Instruction in Improving Coursework", $R Q$, Vol. 26, pp. 207-211.

Larkin, J. E. and Pines, H. A. (2005), "Developing Information Literacy and Research Skills in Introductory Psychology: A Case Study", The Journal of Academic Librarianship, Vol. 31 no.1, pp. 40-45.

Lowell, N. and Collins, L. (2001), "Planning the Assessment. Assessing Student Learning Outcomes in Information Literacy Programs", ALA Preconference Workshop, Office of Educational Assessment, University of Washington, Seattle, Washington.

McAdoo, M. L. (2008), A Case Study of Faculty Perceptions of Information Literacy and Its Integration into the Curriculum. Ph.D. diss., Indiana University of Pennsylvania, Indiana, Pennsylvania.

Peary, A and Ernick, L. (2004), "Reading, Writing, Research: Incorporating Strategies from Composition and Rhetoric into Library Instruction", College and Undergraduate Libraries, Vol.11 no. 1, pp. 33-43.

Purdue, J. (2003), "Stories, Not Information: Transforming Information Literacy", portal: Libraries and the Academy, Vol. 3 no. 4, pp. 653-662.

Smith, R. L. (1997), "Philosophical Shift: Teach the Faculty to Teach Information Literacy", Conference Paper, ACRL National Conference in Nashville, Tennessee.

Thompson, G. (2002), "Information Literacy Accreditation Mandates: What They Mean for Faculty and Librarians", Library Trends, Vol. 51 no. 2, pp. 218-241.

Tompkins, J. (1987), "Me and My Shadow", New Literary History, Vol. 19 No. 1, pp. 169-78

Tompkins, J. (1994), “Textualism, Morality and the Problem of History”, In Goldstein, P. (Ed.), Styles of Cultural Activism, University of Delaware Press, Newark, Delaware, pp. 184-202.

Western Washington University Libraries. "Western Libraries Information Literacy Learning Outcomes." http://www.library.wwu.edu/ref/inst/info_lit_outcomes.htm. [Accessed 29 March 2010].

Young, V. E. and Ackerson, Linda G. (1995), "Evaluation of Student Research Paper Bibliographies: Refining Evaluation Criteria", Research Strategies, Vol. 13 no. 2, pp. 
80-93.

\section{APPENDIX A}

\section{ACS 499 LEARNING OUTCOMES}

1-Examine relationships that are shaped by inequalities of power and identities such as race/ethnicity, national origin, gender, religion, class, ability and sexualities within and between cultural groups. All assignments

2-Apply relevant methodologies and acquire requisite oral and writing skills that will enable them to contribute to the field of American cultural, ethnic and multicultural studies. All assignments

3-Identify and describe a manageable research topic or other information need appropriate to the scope of research questions in American Cultural Studies. Topic statement

4-Read background sources in discipline relevant to the topic within the context of American Cultural Studies to increase familiarity with the topic. Article analysis

5-Identify and list key concepts, terms, social theories, culture groups, places and names related to the topic in preparation for searching for information on it. (use discipline focused encyclopedias, dictionaries, thesauri and glossaries). Research strategy

6-Reevaluate the nature and extent of the information need to clarify, revise, or refine the question after some initial research, reading, interviews, and work with data and/or a population have taken place. Restate topic

7-Select the most appropriate sources and databases for accessing and obtaining the needed information. Research strategy

8-Construct, implement and refine well-defined search strategies that use a variety of methods to find information. Research strategy

9-Summarize the main ideas to be extracted from the information gathered and synthesize main ideas to construct new concepts. Article analyses and annotated bibliography

a. keep track of the information and its sources.

b. record all citation information for future reference.

10-Seek differing viewpoints in alternative databases, books, web sites and articles evaluating the source of the information or argument and determine whether to incorporate or reject viewpoints encountered. Annotated bibliography 


\section{Page 14 of 15}

11-Compare new knowledge with prior knowledge to determine the value added, contradictions, or other unique characteristics of the information and take steps to reconcile differences.

\section{Annotated bibliography and outline}

a. maintain a record of the information seeking process in order to explain and

evaluate the research conducted.

b. determine whether the information that was collected satisfies the research need, and select information that provides evidence for the topic, integrates new

information, and draws conclusions based upon information gathered.

12-Apply new information and research results to the planning, creation, and revision of a particular paper, and presentation. Presentation, draft and final paper

\section{APPENDIX B}

\section{RESEARCH STRATEGY}

1. Which of the following resources are appropriate to your topic?

Primary documents

Journal articles

Government information

Books

Statistics

Interviews/oral histories

Approved internet sites

I expect your bibliography to have a minimum of 12 scholarly sources, primarily articles and books. If you choose to use a "scholarly" internet site, please discuss with me to ensure that the site is acceptable.

2. Explain briefly why you might use more articles than books (or vice versa) and why you might use primary documents, interviews etc.

3. Identify the databases you will use to search for journal articles. If you are using mainly fulltext databases, you should also use at least one citation, discipline oriented, database such as America History and Life, ERIC, Anthropology Plus or Sociological Abstracts.

4. Provide some terms that you will use to search for your topic in the online catalog and/or in databases. 


\section{Page $\mathbf{1 5}$ of $\mathbf{1 5}$}

\section{(c) Emerald Group Publishing Limited}

This is a pre-print of a paper and is subject to change before publication. This pre-print is made available with the understanding that it will not be reproduced or stored in a retrieval system without the permission of Emerald Group Publishing Limited. 